\title{
Characteristics of Value Added Tax in Bosnia and Herzegovina
}

\author{
MSc Branka Topić-Pavković \\ University of Banja Luka, Faculty of Economics \\ branka.topic-pavkovic@efbl.org
}

Doi:10.5901/mjss.2015.v6n2s2p79

\begin{abstract}
In every national economy primary role of the fiscal system is to provide public revenue to finance public needs. In addition, fiscal system has also the task to achieve appropriate economic goals such as export promotion, investment growth, and development of SME. Taxes represent one of the most important instruments for achievement of these goals. Introduction of Value Added Tax in Bosnia and Herzegovina has caused slight inflation on the one hand, while on the other hand has helped increase export, increase collection of tax revenues, regulate economic area creating more favorable legal and economic environment, which improved the basis for further economic development. Indirect Taxation System of Bosnia and Herzegovina has conducted successful introduction of new tax system, which replaced sales tax applicable at that time. This step was rated as one of the key steps for the establishment of single economic area, reduction of the grey economy, and promotion of foreign investments and reduction of the foreign trade deficit. First part of this paper analyzes the concept of value added tax, followed by short history of origin of this form of tax. Further we elaborate basic characteristics of Value Added Tax in Bosnia and Herzegovina, explaining in more details the essence of the term VAT, types of VAT rates, as well as the influence of this measure of fiscal policy to the economic growth and development of Bosnia and Herzegovina. We will overview all the advantages and disadvantages of single VAT rate being applied in our Country.
\end{abstract}

Keywords: fiscal policy, indirect taxation system, value added tax, the rate of value added tax

\section{Introduction}

The tax system does not arise as a result of pre-defined, based on scientific principles of the plan, but on the basis of a compromise of different political forces, under the influence of socio-economic planning, economic development, the degree of openness of the economy, historical development and tradition, the need to find new sources of funding public expenditure. (Pavlović \& Popov, 2003)

Value Added Tax in Bosnia and Herzegovina has replaced Sales tax on goods and services on 01.01.2006. The common feature of both taxes is that they tax consumption. On the basis of information obtained from IBRD, VAT has been introduced in more than 140 countries around the world and is considered to be the most widely used form of tax.

VAT is a multi-stage tax that is calculated and paid at all stages of production and supply of a product and service to the end consumer. This implies that only new value is taxable which is being added at each stage of production.VAT is collected successively into the state treasury as partial payments at every stage of production and supply. When products reach end consumer, state collects full amount of tax.

Basic principles of the introduction of VAT in Bosnia and Herzegovina are:

- Sales tax which was collected at the entity level is replaced with single VAT system at the state level

- Indirect Taxation Authority is the only institution responsible for the calculation and collection of VAT.

- VAT is being paid to the single account opened at Central Bank of Bosnia and Herzegovina

- Law on VAT in Bosnia and Herzegovina is in accordance with 6th EU Directive on VAT.

There are two types of VAT as follows:

- Output VAT - business entities registered for VAT calculate VAT to the taxable supply of goods and services.

- Input VAT - business entities deduct VAT which was calculated by the supplier. services.

From the aforesaid it is clear that business entities pay VAT only to the new value added to their goods and

Process of taxing added value is carried out in following manner:

1. Each company selling its products and services indicates on the invoice as a separate item VAT at the statutory tax rate. This rate is being calculated on the sales value of invoiced products and services. 
2. Buyer of these products and services pays calculated VAT together with the invoiced value, but VAT charged in the supplier's invoice is not included in the cost but is entered within prepayments and accrued income, account-Advance paid VAT.

3. When buyer sells its products and services, VAT is calculated on the invoiced value and entered to the accruals and deferred income, account - Collected VAT.

4. On a maturity date for payment of VAT, balances of accounts Advance paid VAT and Collected VAT are compared:

$>$ Balance of Advance paid VAT<Balance of Collected VAT- difference is paid to the state.

$>$ Balance of Advance paid VAT>Balance of Collected VAT- request is submitted to the state for the refund of excess tax, or tax credit is granted.

Fiscal regulations on VAT stipulate deadline for payment of this tax to the state and usually this is once every 30 days, regardless of the moment of collection of receivables from the buyer, or payment of liabilities to the suppliers. This means that payment deadlines of receivables and deadlines for payment of payables and thereby VAT indicated in the invoice do not coincide with deadlines for payment of a difference between the collected and paid VAT to the state, which may cause additional financial stress to companies.

\section{VAT as an Instrument of Fiscal Policy}

The IMF is committed to the reform of the tax system towards a larger share of consumption tax in relation to the taxation of labor and capital, considering spending less variable tax base in relation to employee wages and profits, which affects the stable public revenues. The recently published OECD studies are based on theoretical and empirical indicators, ranking established forms of taxation according to economic efficiency.

Recurrent taxes on the (fixed) assets are ranked as the most economically efficient form of taxation, while the second is the taxation of consumption. Labour taxation is ranked in third place, while the taxation of capital occupies the last place, as a tax form that has the most negative impact on economic growth as increasing burdens on the economy through taxation of labor and capital reduces the possibilities of the economy for new investment and new jobs. (Johansson, Brys \& Vartia, 2008)

Fiscal policy measures may help overcome the short-term problems caused by disturbances in the economy, but also influence the long-term increase of GDP and income per capita. Fiscal policy measures are intended for the achieving optimum rate of economic growth and not the maximum. VAT represents one of these instruments that can help achieve adequate economic growth. Influence of VAT to the economic growth and development may be shown from the perspective of its: (Musgrave, 1959)

- Allocative,

- Redistributive, and

- Stabilization function

Allocative function - VAT may influence improvement of efficiency of resource allocation, i.e. resource allocation can be made more efficient. Certain products and services by nature appear as goods of general public importance, and may not be submitted to the market mechanisms, and require state intervention. Exemption from payment of value added tax of services in the field of education, culture and health-social protection indirectly influence economic growth and development, because these activities contribute overall development of a society as a whole. Exemption of export activities from payment of VAT improves balance of payments with foreign countries. Exemption of banking services from payment of VAT leaves savings exempted from tax, which is stipulated by the law. Non-taxation of savings, as an accumulation sum, creates precondition for investments which may contribute economic development and growth.

Redistributive function - affects the most arrangement of the structure of VAT. Redistributive function does not represent a serious problem if a mechanism of progressive income tax of has been successfully built-in, so the lower income group of taxpayers accomplish relatively acceptable standard of living. Regressivity of value added tax for the purpose of redistribution can be alleviated by combining effects of this tax with other taxes within fiscal system. This possibility for mitigation of regressivity provides higher taxation of certain products and services with selective consumption taxes (excise). In such manner, Law on Excises of Bosnia and Herzegovina states stipulates of goods subject to payment of this type of tax (coffee, petroleum products, cigars, alcohols).

Stabilization function of VAT - fiscal policy has become one of the basic instruments of stabilization policy which influences development and stability of the economy: establishment of savings, the movement of investments, relations within foreign trade exchange, redistribution of national income. One of VAT factors influencing the increase of prices is the chain length of the multistage taxation of supply. If the number of supply stages is higher in certain branch, this leads 
to the greater number of taxation of added value. End effect of longer supply cycle is expressed in the increase of tax amount, and consequently the increase in retail prices of such products. Basic question in the implementation of VAT is referred to the stabilization function of this tax. If you take into account that stabilization function portrays fiscal effects of tax, impact on the level and pricing policy, as well as the practical applicability of certain tax structure in order to provide stable tax revenues, the activity of this vital function reflects efficiency of value added tax.

\section{Concept of Single VAT Rate}

Among European countries, only Bosnia and Herzegovina and Denmark apply single VAT rate to all products without reduced rate for the essential goods. The Law on Value Added Tax in Bosnia and Herzegovina has established single tax rate of $17 \%$, while the rate of $0 \%$ is applied only on exports. In this manner country stimulates export-oriented companies. The single tax rate of $17 \%$, was not changed since its introduction on January 1st, 2006, and there are no signs or concrete initiatives for the introduction of differentiated VAT rates.

Many politicians, citizens and tax experts consider single VAT rate as being regressive, i.e. that it burdens more poor who save little, and spend majority of their income. In order to solve this problem, introduction of differentiated VAT rates is being proposed or introduction of zero rate for the essential goods. In the background of all this criticism, several questions emerge: Is single VAT rate really regressive? Should this problem be solved with introduction of differentiated rate? Does VAT represent threat to a growth and development of the economy? We will try to provide answers to those questions in the following text.

There is ongoing debate about the concept of regressivity, because many experts perceive regressivity differently. The concept is questionable, because the base for calculation is essential-consumption or income, and to which time period these observations refer. Single VAT rate has proportional effect when consumption is base, and regressive effect when calculated by income. The reason lies in the fact that the savings (as a part of income) are being increased when the income rises, and it's necessary to underline base for calculation of VAT. Understanding of regressivity is changed when you perceive it over a long-term, because then burdening income with VAT may become proportional. Namely, consumption taxes tax only consumption, but not the savings. Since the savings represent deferred consumption, at the moment it converts to consumption it shall be subject to VAT. In such manner rich individuals are not exempted from VAT, because they pay VAT when they start spending their savings. This observation significantly changes concept of regressivity. If the income is regarded as income realized during the entire life, then, with assumption that the entire income is spent until the end of life, it is equal to consumption. Then, rich and poor are equally burdened with VAT, because share of VAT in the income is proportional. Finally, we must admit that regressivity is linked to the annual income, and single VAT rate burdens more poor who save less.

Empirical studies on VAT regressivity often support the fact of its uselessness in narrowing of social inequalities. Studies have shown that in Ireland, rich spend their income on food twice as much than poor, although poor spend majority of their income solely on food. Therefore, zero tax on food in Ireland provides two times higher allowance to rich than poor.

Introduction of multiple rates requires some kind of differentiation of taxable products. If vegetables are subject to lower tax rate, does this mean that fresh, canned and frozen fruit is subject to equal or different tax rates? Process of defining products for different rates is very complex and requires professional and intelligent tax administration, which would clearly and strongly explain its decisions to the public. Therefore, introduction of multiple rates is complicated and includes higher costs of tax administration compared to the single rate system.

Introduction of differentiated rate increases administrative costs of tax collection. Country applying VAT with multiple rates must have more officers for processing complex tax returns than country with single VAT rate. Also, costs of calculation and payment of VAT increases for the companies. When switching from single to two rates, costs of tax administration increase five times. Switching to three rates costs increase ten times.

Lower VAT rates do not guarantee lower prices. Namely, lower VAT rates for medicines or food does not automatically mean lowering of prices of these products. Prices are created on free market according to the supply and demand. Traders form their prices depending on the elasticity of demand, i.e. according to what the market will bear, regardless of the determined tax rate. Therefore, lower VAT is no guarantee that poor shall pay lower price for these products.

Previously, we have stated several facts in favor of single VAT rate, but we are aware that in spite of these facts, single rate has its downsides. One of them is that VAT provides great potential for corruption in tax practice, i.e. VAT frauds. Carousel fraud is a synonym for one of the most famous and largest VAT frauds. Carousel or so called tax carousel is a financial fraud caused by abuse of VAT system, leading to the reduction in public revenues of the country 
which was supposed to collect VAT or the country that has made refund of VAT, when there was no trade. This type of fraud is connected to the sale of goods and also to the supply of services. How this type of fraud actually functions? In socalled carousel fraud scheme, most often phantom company - fraudster imports goods in Member Country without VAT, but he latter charges VAT to its customers. While traders - importers regularly disappear before settling their tax liabilities in favor of competent tax administration of their country of residence, while customers have right to deduct VAT paid from their total taxable income. These activities of importers and subsequent sellers cause losses in the state treasury. The most specific feature of this tax fraud is power to repeat the fraud, almost as many times as the perpetrator of fraud wants it.

In order to prevent and to deter individuals, business entities or chain of taxpayers prone to tax frauds from participating in activities which are contrary to the tax laws, and in order to establish system which will provide adequate response of tax authorities of Member Countries, European Commission has in the mid-2013 adopted amendments to the Directive 112, whose implementation started in January 2014. Adopted amendments to the Directive intend to respond promptly to the emergence of new types of tax frauds, which are reported to all Members of the EU. Each Member, which deems it should undertake special measures of protection, may request from the Commission approval of such measures. (Vukmirica \& Špirić, 2005)

The effects of tax frauds within the country are usually significantly higher in value than the frauds related to international transactions, but domestic frauds are more numerous and with smaller amounts. Violation of law and evasion of VAT payment or reduction of tax liability is generally associated with following activities of taxpayers:

- Issuing of false tax invoices with indicated values of deliveries that are lower in value than actual trade, and which are addressed to the non-existing customers, with the aim of reducing the output VAT

- Obtaining of input invoices from the non-existing suppliers in order to increase input VAT

- Inclusion of fictive company into the sales chain between the two existing companies of which one is buyer and other is supplier, so the fictive company serves for reduction of VAT liability, because the seller sells to that company goods at lower prices than actual, which reduces his output VAT, while the buyer receives the invoice with prices that are higher than the market prices and in such manner is entitled to higher input VAT than the actual.

- Inaccurate representation of prepayment/credit in monthly VAT returns for the unfounded request of VAT refund.

- Inaccurate and incomplete bookkeeping that results in a higher input than output VAT, so the taxpayer is not obliged to pay VAT.

- Fictive company without any turnover submits VAT returns showing tax credit and large amount of receivables from Indirect Taxation Authority, and then requesting refund.

\section{Differentiated VAT Rate}

There were numerous discussions about introduction of differentiated VAT rates in Bosnia and Herzegovina even during the period of drafting of the Law on VAT. However, initiative for differentiated rates has become main topic again because of the influence of the economic crisis on social status of population.

Namely, studies conducted by IMF experts suggest that application of differentiated tax rates create adverse effects. When making decisions on multiple VAT rates, focus is mostly on support to the lower income population, and costs of taxpayers and tax administration are out of focus. IMF economists believe that introduction of differentiated VAT rates brings number of negative effects: (Tait, 1988)

- Multiple rates distort both consumer and producer choices;

- Producers always intend to adjust their price with „what the consumer will bear", i.e. in line with what the market will bear. In that manner, traders will try to transfer increased rate to consumers, which would prevent any reduction in prices of lower rate products;

- Favorable treatment of certain goods having substitutes in terms of purpose makes room for constant complaints of the part of a business community producing or selling substitutes;

- Defining goods and services with favorable treatment, especially „essential goods“, books, medicines and etc., represents problem considering wide range of products and "grey zone" which exist with such range of goods, and is expensive, because it requires engagement of special staff within tax administration, which must have excellent knowledge in production technologies of goods under favorable treatment, substitutes and all other products and brands which are part of "grey zone" and additional human resources which will communicate 
with taxpayers and respond to their inquiries in connection to the taxable status of product, provide binding opinions and supervise implementation of rules and definitions. On the other hand, taxpayers who find themselves in this zone of products have additional expenses associated to their classification and communication with tax administration;

- Lower rates of VAT due to technical problems in application and inability of tax administrations to effectively supervise the implementation of new rules and definitions, definitely leads to tax evasion. Given that tax revenues are part of the total revenues of country, it is clear that tax evasion leads to the reduction in the volume of total revenues of the country, i.e. reduction in total amount of money that state has at its disposal during the budget year;

- The experience of countries show that scale of VAT rates does not contribute changes in preferences of consumers and redistribution within the consumption structure of households and governments, which shows considerable inelasticity of consumption and reflects local character of the goods having favorable tax treatment.

In addition to all aforesaid, it is hard to estimate effects of differentiated rate of VAT to population, tax payers and tax administration, since each of these groups is structured, and the information itself is not representative since there is no dynamic component of long-term development of the economy.

Consumption structure is not only differentiated with regard to the income level, but also with regard to the household age, tendency to saving and investing. When we look at the regressivity of VAT on lower income population, which is one of the main reasons for the introduction of differentiated VAT rates, we must consider net budgetary effects of such measure, weighing the costs incurred by administration and taxpayers due to administration of multiple VAT rates.

However, when it comes to the rate of VAT being reduced, benefits of such rate will have not only the lower classes, but also middle and upper classes. However, practice have shown quite different effects, e.g. reduced rates on baby equipment, baby clothing, shoes or food did not lead to the increase of birth rate. Namely, level of effects of reduced VAT rates depends on:

- Consumer preferences;

- Price elasticity of demand for certain goods and services;

- Level of competition within the sector;

- Level of "gray economy", and etc.

It is possible to achieve many positive effects by lowering VAT rate if this is limited to the sectors that have been affected by "grey economy." If rates are reduced on goods or services that many produce or use, there will be a greater demand for such goods or services supplied by registered suppliers. This leads to better work at formal economy, instead of employees working on principle "do it yourself." Growth of productivity leads to the economies of scale, while moving consumption towards regular market leads to the increase in demand for goods and services, which inevitably leads to the employment growth in this filed and development of the economy, which all together leads to the growth of tax revenues. Lower rate of VAT influences lower unemployment if applied to luxury goods, i.e. goods and services with elastic demand. On the other hand, lower rate of VAT applied to essential products shall not lead to higher demand and growth in employment. But we should not forget that market is quit rigid and depends on many factors, and it takes a lot of time for the change of VAT rate to show targeted effects.

Practice has shown that lower rates of VAT have greatest impact on products of final consumption, locally delivered. If the rate is lower for regional goods, and if we take into account movement of population and labor market, effects of lower rate shall become invisible. Higher consumption of such products will create price that is above desired sales price. We cannot forget the intermediate products and raw materials, where VAT is not an element of cost and does not affect selling prices in the sector.

\section{Value Added Tax in European Countries}

At the beginning of 2014, VAT was increased in three countries within the European Union. In Croatia reduced rate was increased from 10\% to 13\%, in France from $7 \%$ to $10 \%$, and standard rate from $19,6 \%$ to $20 \%$, while in Cyprus reduced rate was increased from $8 \%$ to $9 \%$ since 13.01 .

When new VAT rate was announced in Croatia since 2014, this meant that for the next three months higher VAT should have been applied to edible oils and fats, white sugar, baby food, water supply, catering and tourist services, certain newspaper and magazines, tickets for concerts and culture and art magazines. New tax change brings further 
tensions into economy and sends message about unstable tax environment. With the increase of reduced VAT rate to $13 \%$, Croatia is again among the recorders in the European Union, because this brings Croatia to fourth place, after Hungary (18\%), Finland (14\%) and Ireland (13,\%). VAT rates ):

When we talk about Montenegro, there are two tax rates (meaning that Montenegro has a system of differentiated

- Standard rate of $19 \%$, and

- Reduced rate of $7 \%$.

- Zero rate applies to: export transactions and delivery of medicines and medical devices financed from funds of the Republic Health and Insurance Fund.

Reduced VAT rate of $7 \%$ is applied to:

- essential food products (milk, bread, fat, oil and sugar);

- medicines, including medicines for veterinary use, except prescription medicines covered by the Republic Health and Insurance Fund;

- orthotic and prosthetic devices, as well as medical devices surgically implanted into body, except prescription medical devices covered by the Republic Health and Insurance Fund;

- school books and teaching aids;

- books, monographs and serial publications;

- accommodation in hotels, motels, apart hotels, resorts, guest-houses, camps and villas;

- drinking water, except bottled water;

- daily and periodic newspapers, except press containing mainly or completely advertising content;

- public transportation services and accompanying personal luggage;

- public hygiene services;

- funeral services and products related to such services;

- copyrights and services in the field of education, literature and art;

- copyrights in the field of science and artifacts, collections and antiques;

- services charged through tickets for cinema and theater plays, concerts, museums, fairs, amusement parks, exhibitions, zoos and similar cultural and sport manifestations, except those which are exempt from payment of VAT;

- use of sport facilities for non-profit purposes;

- animal food, fertilizers, plant protection products, seeds for reproduction, planting and breeding stock.

Unlike Montenegro, in Macedonia, we have standard VAT rate of 18\%, and 15\% tax rate on some products. Contributions rate remains unchanged and is $10 \%$. Please note that Macedonia is the only country which did not increase taxes and contributions during the economic crisis. Macedonia did not raise retirement age, salaries and pensions remained the same, and there were no layoffs of administrative workers.

VAT of $20 \%$ is applied in Serbia, Bulgaria, Estonia, Austria, the Netherlands and Slovakia, and in France since 2014.

When we talk about Serbia, where VAT rate is $20 \%$, and reduced rate $10 \%$, which is mainly applied to essential products such as bread, gas, books and etc., in case of inadequacy of general taxation regimen of VAT, it is possible to introduce in accordance with EU Directive, special tax regimes, which are used in case of:

- Small taxpayers;

- Taxpayers with annual income below 8 million RSD cannot enter VAT system;

- Farmers-if farmers deliver products to VAT payers, they are entitled to compensation in amount of $5 \%$ (8\% since 2013) of the value of received goods and services;

- Tourist agencies, and

- Sale of second-hand goods, arts, collection pieces, tax base is determined as a difference between the sale and purchase price, with deduction of VAT contained in the difference.

However, countries have the right to apply in certain circumstances super reduced VAT rates or even tax exemptions. Many countries within European Union apply these measures to the newspapers and books that because of this have better tax treatment, than, for example in Serbia.

According to the EU regulations, VAT rate must be at least 15\% and reduced 5\%. (Vukmirica and Spiric, 2005) However, Member Countries which due to regulations in the EU had to increase their tax rates by more than two percentage points in 1993 may also apply the reduced rate of 5\% to permitted products and services. 


\section{Conclusion}

VAT is the most widely used system of taxation of goods and services in the world, enabling higher public revenues. Bosnia and Herzegovina and Denmark are the only countries in Europe using single VAT rate, which means that the same rate is applied to all products and services, while other countries use differentiated VAT rates, i.e. different rates for different products and services. Introduction of single rate is quite easy and does not require higher costs. However, reduction of VAT rate, does not necessarily mean that poor will pay lower prices, because traders shall continue to form the price according to what the market will bear. Implementation of differentiated rates going down, although the prices will be lower for the essential products, will not lead to the increase in employment. Differentiated VAT rates create higher costs and require more time before the start of implementation and for monitoring of implementation. However, introduction of VAT in Bosnia and Herzegovina should keep the same food prices.

The Law on Value Added Tax is being applied in Bosnia and Herzegovina since 01.01.2006. Indirect Taxation Authority of Bosnia and Herzegovina has promptly and successfully introduced new tax system, which replaced then applicable sales tax. This was rated by relevant international institutions as one of the key steps for establishment of single economic area, reduction of grey economy, encouraging of foreign investments and reduction in the foreign trade deficit. The Law on Value Added Tax in Bosnia and Herzegovina has established single tax rate of $17 \%$, while the rate of $0 \%$ is applied only on exports. In this manner country stimulates export-oriented companies. Introduction of Value Added Tax in Bosnia and Herzegovina has resulted in significant increase in collected revenues. When deciding on introduction of VAT, we must also take into account disadvantages of value added tax, such as high costs of introduction into the tax system and implementation, then, due to the high number of taxpayers, calculation and collection technique is expensive, and in the end, is paid by the economy in each stage of supply before the consumer, which means that the economy is crediting the country.

However, since Bosnia and Herzegovina aspires joining European Union, introduction of VAT state level is one of the fundamental conditions for accession to the European Union, so the existence of this type of tax substantially contributes tendency of Bosnia and Herzegovina to join trend implemented by other Member Countries.

\section{References}

Indirect Taxation Authority in Bosnia and Herzegovina. [Online] Available: http://www.new.uino.gov.ba/ (January 17, 2015)

Johansson, A.; Arnold, J.; Brys, B. \& Vartia, L. (2008). Taxation and Economic Growth. Economics Department Working Paper No. 620, OECD, Paris.

Law on Value Added Tax in Bosnia and Herzegovina. [Online] Available: www.uino.gov.ba/download/Dokumenti/.../Law_on_ VAT_BiH.pdf (January 11, 2015)

Ministry of Finance and Treasury of Bosnia and Herzegovina. [Online] Available: http://www.mft.gov.ba/ (February 3, 2015)

Musgrave, R. (1959). The Theory of Public Finance. New York: McGraw-Hill

Pavlović, Đ., \& llić P. G. (2003). Leksikon javnih finansija. Belgrade: Zavod za unapređenje i rentabilnost poslovanja.

Tait, A., A., (1988), Value Added Tax. [Online] Available: http://www.imf.org/external/pubs/cat/longres.cfm?sk=127.0 (February 4, 2015)

Vukmirica, V., \& Špirić, N. (2005). Ekonomska i monetarna integracija Evrope. Banja Luka:Faculty of Economics 
